\title{
Endophytic bacteria of healthy rice plants origin produce antifungal volatile compound inhibiting the in vitro growth of Pyricularia oryzae Cav., the causal agent of rice blast disease
}

\author{
Fitri Widiantini ${ }^{1}{ }^{*}$ dan Fuji Hartati ${ }^{2}$ \\ ${ }^{1}$ Departemen Hama dan Penyakit Tumbuhan, Fakultas Pertanian, Universitas Padjadjaran \\ ${ }^{2}$ Program Studi Agroteknologi, Fakultas Pertanian, Universitas Padjadjaran \\ *Corresponding Author: fitri.widiantini@unpad.ac.id
}

Received June 18, 2020; revised June 18, 2020; accepted June 30, 2020

\begin{abstract}
Endophytic bacteria have been known as producers for bioactive compound in which have been widely used in the field of crop protection. Several isolates of endophytic bacteria have demonstrated their potential ability as biocontrol agents by inhibiting the development of major rice pathogens. However, their ability to produce bioactive compounds has not been explored. This study reported the ability of the endophytic bacteria isolates in producing antifungal volatile compounds to inhibit the in vitro growth of Pyricularia oryzae Cav., the causal agent of rice blast disease. The experiment was conducted by dual culture method using bipartite compartments in which the bacterial isolates and $P$. oryzae were grown separately and placed by facing to each other. The bacterial isolates were grown on ISP2 agar media, whereas P. oryzae was grown on PDA media. Nine isolates were tested for their ability in producing antifungal volatile compound. The potential of antifungal volatile compound was observed by the $P$. oryzae growth compared to control. Furthermore, its effect on the P. oryzae mycelia was observed under microscope. The result demonstrated that all of the endophytic bacteria tested strongly suspected to produce volatile compounds which were able to inhibit the growth of $P$. oryzae and causing mycelial malformation. Further research is needed to identify the types of volatile compounds produced.
\end{abstract}

Keywords: biological control agent, growth inhibition, malformation

\section{ABSTRAK}

Bakteri endofit asal tanaman padi sehat menghasilkan senyawa volatil yang menghambat pertumbuhan Pyricularia oryzae Cav., patogen penyebab penyakit blas secara in vitro

Bakteri endofit telah dikenal sebagai salah satu sumber penghasil senyawa yang dapat digunakan dalam bidang perlindungan tanaman. Beberapa bakteri endofit asal tanaman padi telah menunjukkan potensinta untuk dikembangkan sebagai agens biokontrol. Hal ini ditunjukkan dengan kemampuannya dalam menghambat pertumbuhan beberapa patogen utama pada tanaman padi. Akan tetapi, isolat bakteri endofit tersebut belum diketahui kemampuannya dalam menghasilkan senyawa volatil yang dapat menekan pertumbuhan jamur patogen Pyricularia oryzae Cav., penyebab penyakit blas. Percobaan dilakulan dengan menggunakan metoda dual culture pada dua kompartemen terpisah, sehingga isolat bakteri dan patogen saling berhadapan namun tidak terjadi kontak fisik satu sama lain. Bakteri endofit yang diuji sebanyak sembilan isolat. Isolat bakteri endofit ditumbuhkan pada media ISP2 sementara $P$. oryzae ditumbuhkan pada media PDA. Deteksi potensi antifungal senyawa volatil yang dikeluarkan bakteri endofit dilakukan dengan mengamati pertumbuhan koloni $P$. oryzae dibandingkan dengan kontrol. Pengaruh senyawa volatil terhadap miselia $P$. oryzae juga diamati secara mikroskopis. Hasil penelitian menunjukkan bahwa semua isolat bakteri endofit yang diuji diduga kuat dapat menghasilkan senyawa volatil yang menghambat pertumbuhan koloni jamur $P$. oryzae serta menyebabkan kerusakan morfologi (malformasi) pada hifanya. Penelitan lebih lanjut diperlukan untuk mengidentifikasi jenis senyawa volatil yang dihasilkan.

Keywords: agens biokontrol, penghambatan koloni, malformasi

\section{PENDAHULUAN}

Jamur patogen Pyricularia oryzae Cav. (teleomorf Magnaporthe grisea), penyebab penyakit blas pada padi, merupakan salah satu patogen penting pada tanaman padi yang dapat menimbulkan kehilangan hasil yang cukup serius. Suganda dkk. (2016) melaporkan bahwa penyakit ini dapat menyebabkan kehilangan hasil hingga mencapai $61 \%$ di daerah endemik. Patogen ini merupakan salah satu di antara sepuluh patogen yang dapat mengancam ketahanan pangan dunia (Zhang et al., 2014). Berdasarkan cara penyerangannya, penyakit blas dapat dipisahkan sebagai blas daun yang menyerang daun padi, dan blas leher yang menyerang malai. Blas leher menyebabkan kerugian yang lebih serius dibandingkan dengan blas daun karena dapat menghambat pengisian malai (Zhuang et al., 2002).

Pengendalian penyakit pada tanaman secara biologi telah mendapat perhatian selama beberapa waktu karena menawarkan alternatif pengendalian yang lebih ramah lingkungan. Penggunaan bakteri endofit sebagai agens biokontrol memberikan keuntungan karena lebih adaptif terhadap kondisi spesifik tanaman (Brader et al., 2014). Salah satu 
mekanisme biokontrol yang penting dari bakteri endofit adalah kemampuannya dalam menghasilkan senyawa metabolit sekunder yang salah satu jenis di antaranya adalah senyawa volatile (Kai et al., 2009).

Senyawa volatil organik dapat dihasilkan oleh semua mikroorganisme, namun jenis senyawa yang dihasilkan tidak sama. Senyawa volatil organik yang dihasilkan mikroba memiliki jenis dan kelas yang luas, dapat berupa asam lemak dan turunannya (hidrokarbon, alkohol dan keton alifatik), senyawa aromatik, senyawa yang mengandung nitrogen, dan senyawa sulfur yang mudah menguap (Schulz \& Dickschat, 2007).

Senyawa volatil yang dihasilkan mikroba memiliki fungsi yang beragam untuk kelangsungan hidup dalam lingkungannya. Menurut Kai et al. (2009), senyawa volatil mikroba dapat berfungsi sebagai infokimia untuk komunikasi intraspesifik dan interspesifik, komunikasi antar sel, memungkinkan pelepasan karbon, serta perangsang dan penghambat tumbuh. Emisi senyawa volatil oleh mikroorganisme dalam tanah dapat memengaruhi pertumbuhan tanaman. Kehadiran senyawa volatil dari strain bakteri tertentu telah terbukti dapat meningkatkan biomasa tanaman bagian akar (Becerra et al., 2011). Beberapa kelompok PGPR (Plant Growth Promoting Rhizobacteria) mampu memodulasi pertumbuhan tanaman Arabidopsis thaliana dengan menghasilkan senyawa volatil guna merangsang tanaman dalam memproduksi hormon tanaman (Ryu et al., 2003).

Pemanfaatan senyawa volatil asal bakteri dalam bidang perlindungan tanaman cukup potensial. Beberapa hasil penelitian menunjukkan bahwa senyawa volatil organik asal bakteri mampu bersifat nematisidal ( $\mathrm{Gu}$ et al., 2007) dan bersifat antijamur (Yuan et al., 2017). Lebih lanjut dilaporkan pula oleh D'Alessandro et al. (2014) bahwa senyawa volatil yang dikeluarkan oleh bakteri endofit dapat meningkatkan ketahanan tanaman. Penelitian ini melaporkan kemampuan beberapa isolat bakteri endofit asal tanaman padi sehat dalam menghasilkan senyawa volatil yang dapat memengaruhi pertumbuhan jamur $P$ oryzae.

\section{BAHAN DAN METODE}

Perbanykkan isolat bakteri endofit dan jamur $\boldsymbol{P}$. oryzae

Isolat bakteri endofit (Os1, Os2, Os3, Os4, Os5, Os6, Os7, Os8 dan Os10) dan jamur patogen $P$. oryzae yang digunakan pada penelitian ini merupakan koleksi dari Laboratorium Bioteknologi Proteksi Tanaman, Fakultas Pertanian, Universitas Padjadjaran. Bakteri endofit diisolasi dari berbagai bagian tanaman padi sehat baik daun, batang maupun akar dan menunjukkan aktivitas antifungal terhadap $P$. oryzae (Widiantini et al., 2017), Cercospora oryzae dan Bipolaris oryzae (Fiko \& Widiantini, 2018). Bakteri endofit ditumbuhkan dan diperbanyak pada media ISP2 (International Streptomyces Project 2) (4 g ekstrak yeast, $10 \mathrm{~g}$ ekstrak malt, $4 \mathrm{~g}$ glukosa, $20 \mathrm{~g}$ agar, 11 akuades, pH 7,2 $\pm 0,2$ ), sementara jamur $P$. oryzae ditumbuhkan dan diperbanyak pada media PDA (Potato Dextrose Agar) (Oxoid).

\section{Deteksi aktivitas antifungal senyawa volatil yang dihasilkan oleh bakteri endofit}

Pengujian senyawa volatil yang dihasilkan isolat bakteri endofit asal tanaman padi dilakukan dengan metode dual culture pada dua Petri dish terpisah yang dimodifikasi dari Kai et al. (2007). Masing-masing petri dish yang berisi isolat bakteri endofit dan $P$. oryzae dipasangkan secara berhadapan (Gambar 1). Media PDA dan ISP2 padat masingmasing sebanyak 15-20 ml dituangkan ke dalam dua petridish yang berbeda. Setelah media dingin dan padat, sebanyak satu plug (diameter $6 \mathrm{~mm}$ ) jamur $P$. oryzae berumur 7 hari diletakkan di tengah-tengah Petri dish berisi media PDA, sedangkan solat bakteri endofit yang akan diuji ditumbuhkan dengan cara menggoreskan satu ose penuh koloni bakteri endofit pada Petri dish lain yang berisi media ISP2 padat secara merata sehingga memenuhi seluruh permukaan agar media.

Kedua Petri dish berisi P. oryzae dan isolat bakteri endofit tadi dipasangkan dan direkatkan menggunakan cling wrap. Posisi $P$. oryzae berada di bagian atas dan isolat bakteri endofit berada di bagian bawah (Gambar 1). Petridish kemudian diinkubasikan pada suhu ruang dan diamati setiap hari hingga 14 hari setelah perlakuan. Pada perlakuan kontrol, media berisi biakan jamur $P$. oryzae dihadapkan pada media ISP2 tanpa biakan isolat bakteri. Semua perlakuan diulang sebanyak empat kali.

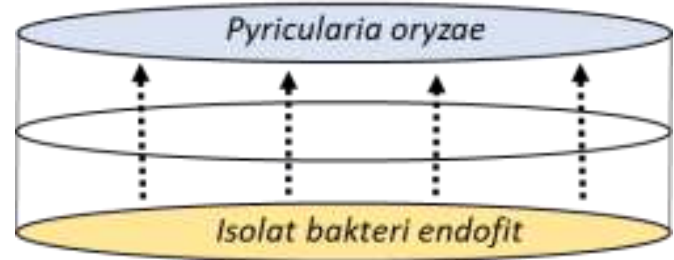

Gambar 1. Ilustrasi pengujian efek volatil isolat bakteri endofit asal tanaman padi terhadap P. oryzae.

\section{Pengamatan}

Pengamatan pengaruh senyawa volatil yang dikeluarkan oleh isolat bakteri endofit terhadap pertumbuhan $P$. oryzae dilakukan setiap hari. Parameter yang diamati adalah diameter koloni $P$. oryzae dan perubahan morfologi $P$. oryzae. Pengamatan secara mikrosopis terhadap kondisi hifa $P$. oryzae pada setiap perlakuan dilakukan pada akhir pengujian, yaitu setelah masa inkubasi 14 HSP (Hari Setelah Perlakuan) dengan perbesaran 400 kali. Persentase penghambatan pertumbuhkan koloni jamur $P$. oryzae oleh senyawa volatil dihitung dengan rumus sebagai berikut: 
Keterangan:

$$
I=\frac{c-t}{c} \times 100 \%
$$

$\mathrm{I}=$ persentase penghambatan

$\mathrm{c}=$ jari-jari koloni $P$. oryzae pada kontrol

$\mathrm{t}=$ jari-jari koloni $P$. oryzae pada perlakuan

\section{Data analisis}

Pengolahan statistik terhadap data hasil percobaan dilakukan menggunakan program $R$ Statistik versi 1.1.456. Analisis data hasil percobaan dilakukan dengan ANOVA kemudian apabila hasil menunjukkan perbedaan yang nyata maka dilakukan uji Tukey HSD sebagai uji lanjutan pada taraf nyata 5\% (Gomez \& Gomez, 1995). Analisis lanjut Uji Tukey HSD dilakukan terhadap jari-jari koloni $P$. oryzae.

\section{HASIL DAN PEMBAHASAN}

Hasil pengujian efek volatil menunjukkan bahwa seluruh isolat bakteri endofit asal tanaman padi diduga kuat mampu menghasilkan senyawa volatil yang bersifat antijamur. Setiap isolat bakteri endofit memiliki kemampuan penghambatan yang berbedabeda. Persentase penghambatan paling besar ditunjukkan oleh isolat bakteri endofit Os1. Besar penghambatan isolat Os1 mencapai $71,51 \%$, sedangkan persentase penghambatan paling rendah ditunjukkan oleh isolat bakteri endofit Os4 dengan persentase penghambatan hanya sebesar 36,28\% (Tabel 1). Semakin besar nilai penghambatan suatu perlakuan, maka semakin kecil ukuran koloni $P$. oryzae yang tumbuh (Gambar 2).

Tabel 1. Pengaruh senyawa volatil yang dikeluarkan oleh isolat-isolat bakteri endofit terhadap pertumbuhan koloni P. oryzae.

\begin{tabular}{cccc}
\hline Perlakuan & Jari-jari P. oryzae (cm) & Persen Penghambatan (\%) \\
\hline Kontrol & 6,67 & a & - \\
Os1 & 1,90 & b & 71,51 \\
Os2 & 3,03 & b & 54,57 \\
Os3 & 2,48 & b & 62,82 \\
Os4 & 4,25 & ab & 36,28 \\
Os5 & 3,25 & b & 51,27 \\
Os6 & 2,90 & b & 56,52 \\
Os7 & 3,50 & ab & 47,52 \\
Os8 & 2,98 & b & 55,32 \\
Os10 & 2,95 & b & 55,77 \\
\hline
\end{tabular}

Keterangan: Angka yang diikuti oleh huruf yang berbeda pada kolom yang sama berbeda nyata berdasarkan Uji Tukey HSD pada taraf nyata $5 \%$

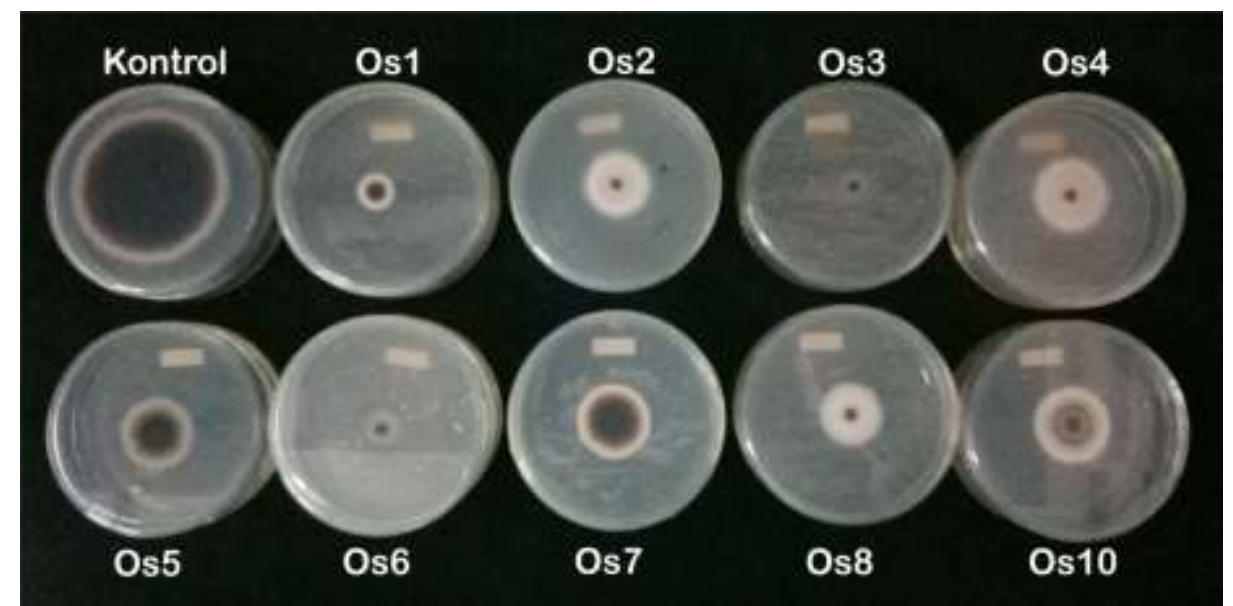

Gambar 2. Hasil pengujian efek volatil asal isolat bakteri endofit padi terhadap pertumbuhan P. oryzae.

Hasil pengujian efek volatil asal isolat bakteri endofit ini memperkuat penelitian yang dilakukan oleh Kai et al. (2007). Pada penelitian tersebut, bakteri antagonis yang diujikan mempengaruhi pertumbuhan miselia Rhizoctonia solani dengan kisaran penghambatan 80-99\%. Respons jamur terhadap senyawa volatil organik yang dihasilkan bakteri dapat berupa penghambatan 
pertumbuhan miselia (Kai et al., 2007), penurunan pertumbuhan dan sporulasi atau perkecambahan spora yang terhambat (Kai et al., 2010). Respons yang terjadi akibat senyawa volatil organik tergantung dari kombinasi bakteri dan jamur yang digunakan (Kai et al., 2007). Jamur yang berbeda dapat memberikan respons yang berbeda. Begitu pun dengan komponen senyawa volatil yang berbeda, titik reaksi yang berbeda, dan kemampuan jamur dalam detoksifikasi paparan senyawa volatil yang berbeda. Bagi bakteri yang mengeluarkan senyawa volatil, emisi senyawa ini memberikan keuntungan bagi bakteri tersebut karena menyebabkan bahan-bahan sisa metabolisme tidak menumpuk pada sel suatu organisme (Kai et al., 2010).

Pengamatan terhadap penghambatan pertumbuhan $P$. oryzae pada penelitian ini juga dilakukan secara mikroskopis. Hasil pengamatan menggunakan mikroskop dengan perbesaran 400x menunjukkan beberapa kelainan bentuk hifa $P$. oryzae. Beberapa bentuk yang tidak normal tersebut di antaranya hifa menggulung, saling melilit, mengeriting, membengkak, hingga plasmolisis (Gambar 3). Ketidaknormalan tersebut teramati dapat ditemukan pada miselia $P$. oryzae yang terpapar pada hampir semua isolat bakteri endofit.

Dalam percobaan ini, efek dari senyawa volatil yang dihasilkan oleh bakteri yang diuji menyebabkan terjadinya berbagai kelainan pada miselium dan hifa jamur $P$. oryzae sebagaimana dideskripsikan di atas. Hasil ini menambahkan temuan yang tidak jauh berbeda dengan yang disampaikan oleh Chaurasia et al., (2005) dan Chen et al. (2008). Chaurasia et al., (2005) melaporkan kelainan berupa pembentukan konidiofor menjadi vegetatif dan terhambat, pembengkakakan hifa, vakuolisasi, dan granulalisasi hingga lisis, sementara Chen et al. (2008) melaporkan bahwa senyawa volatil yang dihasilkan oleh bakteri Bacillus subtilis menyebabkan hifa Botrytis cinirea menjadi kosong.

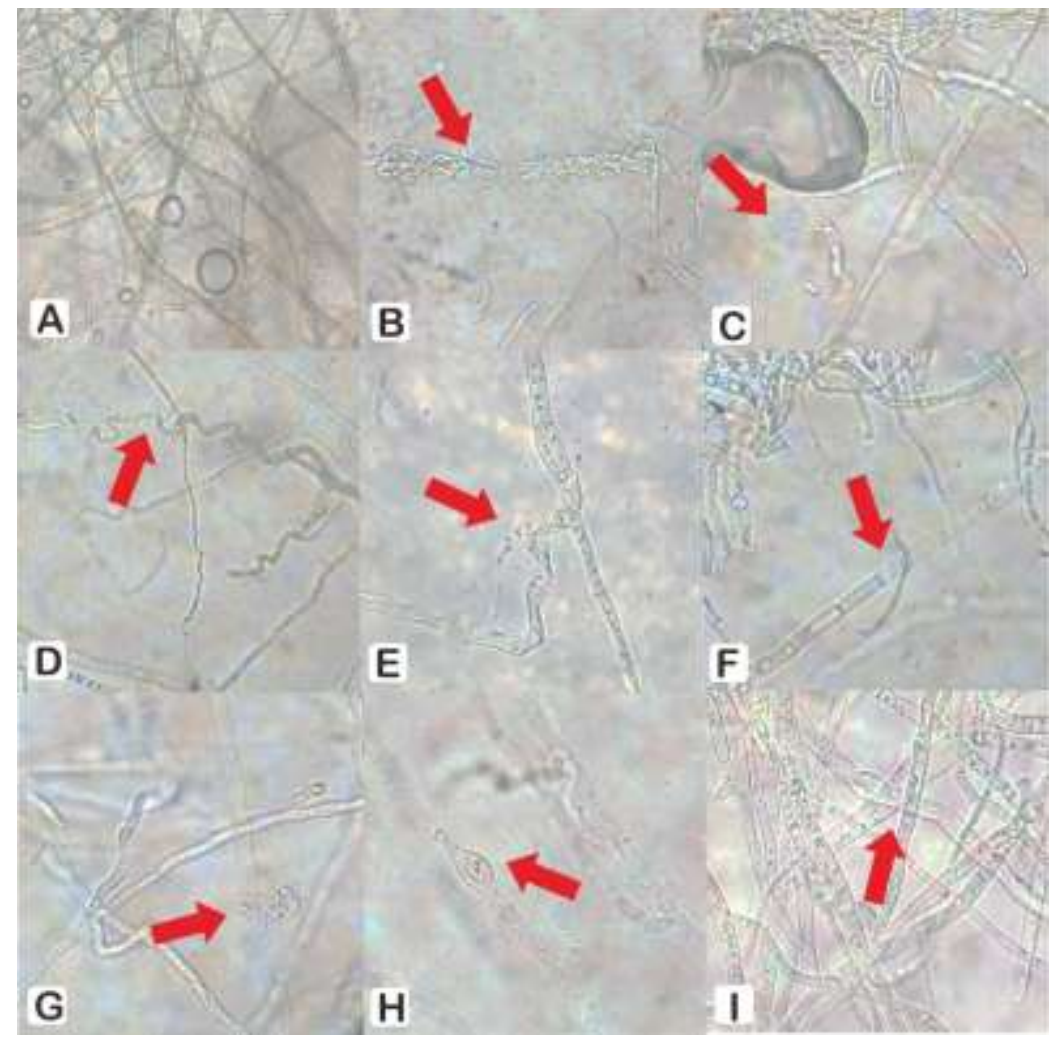

Gambar 31. Hasil pengamatan mikroskopis hasil pengujian efek volatil asal isolat bakteri endofit Os. Hifa P. oryzae pada perlakuan kontrol (A) dan beberapa kelainan hifa, seperti saling melilit (B), patah (C), mengeriting (D), melipat (E), plasmolisis (F), menggulung (G), kosong dan membentuk benjolan (H), dan membengkak (I).

Efek penghambatan terhadap jamur dari senyawa volatil organik bakteri bukan bersifat fungisidal, tetapi fungistatik (Mackie \& Wheatley, 1999 dalam Campos et al., 2010). Fungistatik merupakan suatu sifat senyawa yang hanya dapat menghambat pertumbuhan jamur tanpa mematikannya (Campos et al., 2010). Senyawa volatil organik diproduksi oleh bakteri dari bahan sisa metabolisme primer (aseton, etanol, atau asam lemak) atau metabolit sekunder, sehingga kemungkinan jenis senyawa volatil tersebut sangat beragam (Zhu et al., 2010). Senyawa volatil organik bakteri meliputi senyawa kimia turunan dari asam lemak seperti hidrokarbon, keton, alkohol, asam, sulfur, dan terpen (Audrain et al., 2015). Kai et al. (2008), mengungkapkan bahwa senyawa volatil organik 
bakteri dapat digolongkan menjadi 75 turunan asam lemak, 50 komponen aromatik, 74 kandungan nitrogen, 30 komponen sulfur, 96 terpenoid, dan 18 halogenated, selenium, tellurium, atau bahan metaloid lainnya.

Senyawa volatil yang dapat diemisikan oleh bakteri dapat berupa senyawa anorganik, seperti karbondioksida, hidrogen, karbonmonoksida, amonia, dan HCN (Effmert et al., 2012). Menurut hasil penelitian Ainun (2018), isolat bakteri endofit Os yang mampu memproduksi gas $\mathrm{HCN}$ hanya beberapa isolat, yaitu Os2, Os3, Os4, Os7, dan Os10. Pada percobaan ini, senyawa volatile yang dikeluarkan oleh isolat-isolat tersebut menunjukkan aktivitas menghambat pertumbuhan $P$. oryzae yang cukup baik. HCN dikenal sebagai senyawa antijamur yang diproduksi oleh bakteri. Jenis bakteri yang banyak menghasilkan HCN diantaranya adalah bakteri dari kelompok Bacillus, Pseudomonas, dan Streptomyces dan telah dilaporkan mampu menekan pertumbuhan jamur melalui senyawa volatil yang dihasilkannya (Weisskopf, 2013). Zhao et al., (2011) melaporkan bahwa senyawa volatil jenis benzothiazol menyebabkan percabangan lebih pada miselium dan meningkatkan produksi konidia, sedangkan senyawa citronellol hanya menginduksi penyempitan hifa.

Jenis senyawa volatil pada setiap jenis bakteri sangat beragam. Dimethyl disulfide dan dimethyl trisulfide merupakan senyawa volatil yang dominan ditemukan pada beberapa bakteri golongan Actinomycetes (Wilkins, 1996). Streptomyces merupakan salah satu kelompok bakteri yang mampu menghasilkan senyawa volatil. Sebanyak 536 jenis senyawa volatil organik ditemukan dari 12 isolat Streptomyces yang diisolasi dari rhizosfer (Cordovez et al., 2014). Senyawa volatil tersebut berasal dari berbagai jenis seperti alkohol, aldehid, asam karboksil, ester, keton, sulfur, dan beberapa jenis terpen. Diantara senyawa volatil tersebut 45 jenis diproduksi oleh semua isolat Streptomyces. Penelitian Cordovez et al. (2014) memperkuat pernyataan bahwa senyawa volatil organik dari Streptomyces tersebut memiliki aktivitas antijamur, yaitu terhadap $R$. solani. Strepromyces strain W47 dan W214 yang paling tinggi menghambat $R$. solani dengan persentase penghambatan $57 \%$ dan $47 \%$.

Sayangnya senyawa volatil yang dihasilkan oleh isolat-isolat bakteri endofit pada penelitian ini tidak dapat dianalisis lebih lanjut. Ekstraksi senyawa volatil dapat dilakukan dengan menggunakan activated charcoal dan kemudian diidentifikasi dengan menggunakan metode GC-MS (Gas Chromatography-Mass Spectroscopy) (TenorioSalgado et al., 2014). Akan tetapi karena berbagai keterbatasan alat dan bahan, pada penelitian ini hal tersebut tidak dapat dilaksanakan.

\section{KESIMPULAN}

Isolat bakteri endofit asal tanaman padi diduga kuat dapat menghasilkan senyawa volatil yang dapat menghambat pertumbuhan jamur dan dapat mengakibatkan terjadinya malformasi pada miselia $P$. oryzae. Senyawa volatil ini berpotensi untuk dikembangkan sebagai bahan aktif fungisida, sehingga diperlukan penelitian lanjutan untuk mengidentifikasi jenis senyawanya.

\section{DAFTAR PUSTAKA}

Ainun K. 2018. Aktivitas Bakteri Endofit Asal Tanaman Padi dalam Mendegradasi Kitin, Melarutkan Fosfat, dan Menghasilkan Asam Sianida (HCN). Universitas Padjadjaran. Skripsi (Tidak Dipublikasikan).

Audrain B, Farag MA, Ryu C, \& Ghig JM. 2015. Role of bacterial volatile compounds in bacterial biology. FEMS Microbiology. 3: 222-233.

Becerra CV., Macías-Rodríguez LI, López-Bucio J, Altamirano-Hernández J, Flores-Cortez I, \& Valencia-Cantero E. 2011. A volatile organic compound analysis from Arthrobacter agilis identifies dimethylhexadecylamine, an amino-containing lipid modulating bacterial growth and Medicago sativa morphogenesis in vitro. Plant and Soil. 339: 329-340.

Brader G, Compant S, Mitter B, Trognitz F, \& Sessitsch A. 2014. Metabolic potential of endophytic bacteria. Current Opinion in Biotechnology: 27, 30-7.

Campos VP, de Pinho RSC, \& Freire ES. 2010. Volatiles produced by interacting microorganisms potentially useful for the control of plant pathogens. Ciênc. Agrotec. Lavras. 34(3): 525-535.

Chaurasia B, Pandey A, Panli LMS, Trivedi P, Kumar B, \& Colvin N. 2005. Diffusible and volatile compounds produced by an antagonistic Bacillus subtilis strain cause structural deformations in pathogenic fungi in vitro. Microbiological Reseacrh. 16: 75-81.

Chen H, Xiao X, Wang J, Wu L, Zheng Z, \& Yu Z. 2008. Antagonistic effects of volatiles generated by Bacillus subtilis on spore germination and hyphal growth of the plant pathogen, Botrytis cinerea. Biotechnology Letters. 30: 919-923.

Cordovez V, Carrion VJ, Etalo DW, Mumm R, Zhu H, van Wezel GP, \& Raaijmakers JM. 2014. Diversity and functions of volatile organic compounds produced by Streptomyces from a disease-suppressive soil. Frontiers in Microbiology. 6: 1-13.

D'alessandro M, Erb M, Ton J, Brandenburg A, Karlen D, Zopfi J, \& Turlings TCJ. 2014. Volatiles produced by soil-borne endophytic bacteria increase plant pathogen resistance and affect tritrophic interactions. Plant, Cell and Environment. 37: 813-26.

Effmert U, Kalderás J, Warnke R, \& B. Piechulla. 2012. Volatile mediated interactions between 
bacteria and fungi in the soil. Journal Chemical and Ecological. 38: 665-703.

Fiko DSA, \& Widiantini F. 2018. Uji antagonisme bakteri endofit dengan Cercospora oryzae Miyake dan Biplaris oryzae (Breda de Haan) Shoemaker. Jurnal Agrikultura. 29: 131-5.

Gomez KA, \& Gomez AA. 1995. Prosedur Statistik untuk Penelitian Pertanian. Jakarta: UI Press.

Gu YQ, Mo MH, Zhou JP, Zou CS, \& Zhang KQ. 2007. Evaluation and identification of potential organic nematicidal volatiles from soil bacteria. Soil Biology and Biochemistry. 39: 2567-2575.

Kai M, Crespo E, Cristescu SM, Harren FJM, Francke W, \& Piechulla B. 2010. Serratia odorifera: Analysis of volatile emission and biological impact of volatile compounds on Arabidopsis thaliana. Applied Microbial and Cell Physiology. 88: 965-976.

Kai M, Haustein M, Molina F, Petri A, Scholz B, \& Piechulla B. 2009. Bacterial volatiles and their action potential. Appl Microbiol Biotechnol. 81: 1001-1012.

Kai M, Effmert U, Berg G, \& Piechulla B. 2007. Volatiles of bacterial antagonists inhibit mycelial growth of the plant pathogen Rhizoctonia solani. Arch Microbiology. 187: 351-360.

Ryu CM, Farag MA, Hu CH, Reddy MS, Wei HX, \& Kloepper JW. 2003. Bacterial volatiles promote growth in Arabidopsis. Proceedings of the National Academy of Science of the United States of America. 100: 4927-4932.

Schulz S, \& Dickschat JS. 2007. Bacterial volatiles: the smell of small organisms. The Royal Society of Chemistry. 24: 814-842.

Suganda T, Yulia E, Widiantini F, \& Hersanti. 2016. Intensitas penyakit blas (Pyricularia oryzae Cav.) pada padi varietas Ciherang di lokasi endemic dan pengaruhnya terhadap kehilangan hasil. Jurnal Agrikultura. 27 (3): 154-159.

Tenorio-Salgado S, Tinoco R, Vazquez-Duhalt R, Caballero-Mellado J, \& Perez-Rueda E. 2014. Identification of volatile compounds produce by the bacterium Burkholderia tropica that inhibit the growth of fungal pathogens. Bioengineered. 4: 236-243.

Weisskopf L. 2013. The potential of bacterial volatiles for crop protection against phytophathogenic fungi. In: A. Méndez-Vilas (ed) Microbial pathogens and strategies for combating them: science, technology and education. The Formatex Microbiology Book Series: 13521363.

Widiantini F, Herdiansyah A, \& Yulia E. 2017. Biocontrol potential of endophytic bacteria isolated from healthy rice plant against rice blast disease (Pyricularia oryzae Cav). $\mathrm{KnE}$ Life Sciences, 26: 287-95.

Wilkins K. 1996. Volatile metabolites from actinomycetes. Chemosphere. 32: 14271434.

Yuan J, Zhao M, Li R, Huang Q, Raza W, Rensing C, \& Shen Q. 2017. Microbial volatile compounds alter the soil microbial community. Environmental Science and Pollution Research International. 24 (28): 22485-22493.

Zhang H, Wu Z, Wang V, Li Y, \& Xu JR. 2014. Germination and infectivity of microconidia in the rice blast fungus Magnaporthe oryzae. Nature Communications 5, 4518.

Zhao L, Xiao-Nan Y, Xiang-ying L, Wei M, \& Feng L. 2011. Antifungal, insecticidal and herbicidal properties of volatile components from Paenibacillus polymyxa Strain BMP11. Agricultural Sciences in China. 120: 728736.

Zhuang JY, Ma WB, Wu JL, Chai RY, Lu J, Fan YY, Jin MZ, Leung H, \& Xheng KL. 2002. Mapping of leaf and neck blast resistance genes with resistance gene alanog, RADP and RFLP in rice. Euphytica 128, 363-70.

Zhu J, Bean HD, Kuo YM, \& Hill JE. 2010. Fast detection of volatile organic compounds from bacterial cultures by secondary electrospray ionization-mass spectrometry. Journal of Clinical Microbiology. 48 (12): 4426-4431.

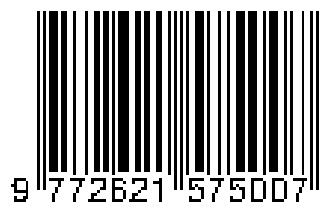

